\title{
Enamel ultrastructure of molars in †Anomalomys gaillardi and some spalacid taxa (Rodentia, Mammalia)
}

\author{
Dariusz Nowakowski, Leonid Rekovets, Oleksandr Kovalchuk, \\ Edward Pawlina, and Vitalii Demeshkant
}

\begin{abstract}
The paper presents results of the study of molar enamel ultrastructure in †Anomalomys gaillardi from the late Miocene and some extinct and recent Spalacidae species (Rodentia, Mammalia) from the territory of Ukraine. We characterize the similarities and differences in the enamel structure between extinct and recent forms, as well as between different taxa within the genera †Anomalomys, †Pliospalax, and Spalax. Analysis shows that the tooth enamel of the studied species is multilayered and differs in the presence of its different types, as well as in the arrangement of prisms. A more complex enamel structure was discovered in †Anomalomys gaillardi from the late Miocene of Ukraine compared to Pliocene †Pliospalax and, especially, Pleistocene and recent Spalax. It allows us to assume that anomalomyids and spalacids are distantly related and they evolved independently.
\end{abstract}

Dariusz Nowakowski. Wrocław University of Environmental and Life Sciences, Department of Anthropology, 5 Kożuchowska st., Wrocław, 51-631 Poland. darekn@hot.pl Leonid Rekovets. Wrocław University of Environmental and Life Sciences, Institute of Biology, 38c Chełmonskiego st., Wrocław, 51-630 Poland. leonid.rekovets@upwr.edu.pl Oleksandr Kovalchuk. National Museum of Natural History, National Academy of Sciences of Ukraine, Department of Paleontology, 15 Bogdan Khmelnytsky st., Kyiv, 01030 Ukraine. biologiest@ukr.net Edward Pawlina. Wrocław University of Environmental and Life Sciences, Department of Genetics, 7 Kożuchowska st., Wrocław, 51-631 Poland. edward.pawlina@upwr.edu.pl Vitalii Demeshkant. Wrocław University of Environmental and Life Sciences, Institute of Biology, 38c Chełmonskiego st., Wrocław, 51-630 Poland, demeshkant@gmail.com

Keywords: evolution; convergence; mole-rats; morphology; teeth; Ukraine

Nowakowski, Dariusz, Rekovets, Leonid, Kovalchuk, Oleksandr, Pawlina, Edward, and Demeshkant, Vitalii. 2018. Enamel ultrastructure of molars in †Anomalomys gaillardi and some spalacid taxa (Rodentia, Mammalia). Palaeontologia Electronica 21.2.18A 1-15. https://doi.org/10.26879/846

palaeo-electronica.org/content/2018/2220-enamel-structure-of-mole-rats

Copyright: May 2018 Paleontological Society.

This is an open access article distributed under the terms of the Creative Commons Attribution License, which permits unrestricted use, distribution, and reproduction in any medium, provided the original author and source are credited.

creativecommons.org/licenses/by/4.0/ 


\section{INTRODUCTION}

Since the second half of the twentieth century, a number of publications have been devoted to studies of the enamel ultrastructure of teeth of vertebrates, mainly mammals (von Koenigswald, 1980, 1997a, 1997b; Martin, 1993, 1997; Kalthoff, 2000; Rekovets et al., 2015). Extinct and recent voles, hamsters, beavers (Rodentia), pikas, hares (Lagomorpha), bats (Chiroptera), wolves, foxes (Carnivora), as well as whales and dolphins (Cetacea) are the most studied groups so far in this aspect (von Koenigswald and Martin, 1984; Stefen, 1999; von Koenigswald and Mörs, 2001; Martin, 2004; Rekovets and Nowakowski, 2013; Loch et al., 2015; Rabiniak et al., 2017).

The enamel ultrastructure has been considered of taxonomic importance (von Koenigswald and Martin, 1984; von Koenigswald, 1997a, 1997b; von Koenigswald and Pfretzschner, 1991). Certain enamel layers were found to be absent in some groups of rodents, e.g., in case of tangential enamel in steppe lemmings (von Koenigswald and Tesakov, 1997) or lamellar enamel in primitive voles (von Koenigswald, 1980). These variations are species-specific and may be typical either for all tooth types or only for certain morphological elements of the same tooth, such as conids in voles (Rekovets and Kovalchuk, 2017) or flexies and fossettes in beavers (Rekovets and Nowakowski, 2013).

The enamel ultrastructure in mole-rats (Spalacidae) and morphologically similar groups is still poorly investigated. There is only a handful of publications (Flynn et al., 1987; Kalthoff, 2000; Rekovets et al., 2015) focusing on specific features of the enamel structure in some species of the genera Rhizomys and †Anomalomys, and representatives of the family Spalacidae as well (von Koenigswald, 2004). Fejfar (1972) suggested that anomalomyids and spalacids are closely related and have evolved from Tachyoryctoidinae. Hugueney and Mein
(1993) argued that Oligocene Tachyoryctoidinae are closely related to Spalacinae because of the presence of derived dental structures. According to Topachevsky (1969), Spalacinae are phylogenetically related to Prospalacinae. However, de Bruijn (1984) suggested that †Prospalax Méhely, 1908 in Méhely (1909) is closer to †Anomalomys than to Spalax, and hence should be included into Anomalomyinae.

The goal of our research is to study in detail the enamel ultrastructure of molars (namely its stratification, the arrangement of prisms, and the IPM structure) in †Anomalomys gaillardi from the late Miocene of Ukraine, as well as in †Pliospalax and Spalax from Eastern Europe. The hypothesis is that the enamel ultrastructure as an additional morphological character would allow us clarifying the issue of phylogenetic affinity of anomalomyids and spalacids.

\section{MATERIAL AND METHODS}

The material for the study is a series of molars belonging to †Anomalomys gaillardi from the late Miocene of Ukraine, extinct species of the family Spalacidae from Pliocene and Pleistocene deposits of Ukraine. The teeth of recent Spalax leucodon and Spalax microphthalmus from southern Ukraine were also studied (Table 1). All examined specimens are deposited in the Department of Paleontology of the National Museum of Natural History, NAS of Ukraine, Kyiv (NMNHU-P). The enamel was studied on transverse sections of the masticatory surface of molars along the entire tooth perimeter, as well as on flexies and fossettes. Here we describe the microstructure of the tooth enamel of abovementioned taxa (in particular, radial and lamellar enamel types in various modifications, prismless external enamel, interprismatic matrix).

The preparation of teeth for the analysis followed von Koenigswald (1980). The specimens were ground immediately after embedding in epoxy

TABLE 1. Distribution of the examined molars by species, geological age, and localities.

\begin{tabular}{|c|c|c|c|c|c|c|c|c|}
\hline \multirow[b]{2}{*}{ Species } & \multirow[b]{2}{*}{ Geological age } & \multirow[b]{2}{*}{ Locality } & \multicolumn{6}{|c|}{ Number of examined teeth } \\
\hline & & & M1 & M2 & M3 & $\mathbf{m 1}$ & m2 & m3 \\
\hline Anomalomys gaillardi & late Miocene & Grytsiv & 1 & 2 & - & 1 & 1 & 1 \\
\hline Pliospalax macovei & early Pliocene & Krasnopol & - & - & 2 & - & - & - \\
\hline Pliospalax odessanus & middle Pliocene & Odesa Catacombs & - & - & 2 & - & - & - \\
\hline Spalax minor & late Pleistocene & Tarkhankut & - & 2 & - & - & - & - \\
\hline Spalax microphthalmus & Recent & southern Ukraine & - & - & 2 & - & - & - \\
\hline Spalax leucodon & Recent & southern Ukraine & - & - & 2 & - & - & - \\
\hline
\end{tabular}


resin (Epoxy Embedding Medium kit - 45359 Sigma-Aldrich $\mathrm{GmbH}$ ). The quality of grinding was controlled under stereomicroscope. The samples were rinsed for 10 seconds in a $5 \% \mathrm{HCl}$ solution followed by ethanol and placed for 30 seconds in the ultrasonic apparatus to remove the dust. The cross sections were standard for all samples and were analysed in a scanning electron microscope Zeiss LEO 435 in the Laboratory of Electron Microscopy, Wrocław University of Environmental and Life Sciences (Poland). The images were taken at different magnifications. Preparation and photographing of examined samples were performed in Wrockaw University of Environmental and Life Sciences.

The taxonomy follows Bolliger (1999) for Anomalomyidae, and Wilson and Reeder (2005) for Spalacidae. The dental nomenclature (Figure 1) follows Topachevsky (1969), Sarica and Şen (2003). The upper molars are abbreviated as M1, $M 2$, and $M 3$, while the lower molars as $m 1, m 2$, and $\mathrm{m} 3$. The enamel terminology follows von Koenigswald and Sander (1997). The regional subdivision of the eastern Paratethys stages follows Topachevsky et al. (1997, 1998), Nesin and Nadachowski (2001), while the land mammalian zonation follows Mein (1999).

Abbreviations used: HSB, Hunter-Schreger bands; EDJ, enamel-dentine junction; IPM, interprismatic matrix; L, lamellar enamel type; MN, Mammal Neogene Zone; MQR, Mammal Quaternary Rodent Zone; OES, outer enamel surface; PLEX, prismless external enamel; $\mathbf{R}$, radial enamel type.

\section{SYSTEMATIC PALEONTOLOGY}

\section{Family †ANOMALOMYIDAE Schaub, 1925 Genus †ANOMALOMYS Gaillard, 1900}

Type species. †Anomalomys gaudryi Mein and Freudenthal, 1971

†Anomalomys gaillardi Viret and Schaub, 1946 Figures 2-6

Material. One M1, two M2, one $\mathrm{m} 1$, one $\mathrm{m} 2$, one m3. All from the Grytsiv locality (late Miocene, MN 9), western Ukraine.

Description. The entire perimeter of the M1 (Figure 2.1-6) consists of enamel composed of two distinct types: the outer radial (ca. $40 \%$ of the total enamel thickness) and the inner lamellar (ca. 60\% of the enamel thickness). Well-pronounced prisms in the radial enamel have a strictly linear arrangement from the EDJ to the OES (Figure 2.2-3). In the lamellar enamel, prisms are clearly visible and arranged in the inclined lamellar way (Figure 2.5).

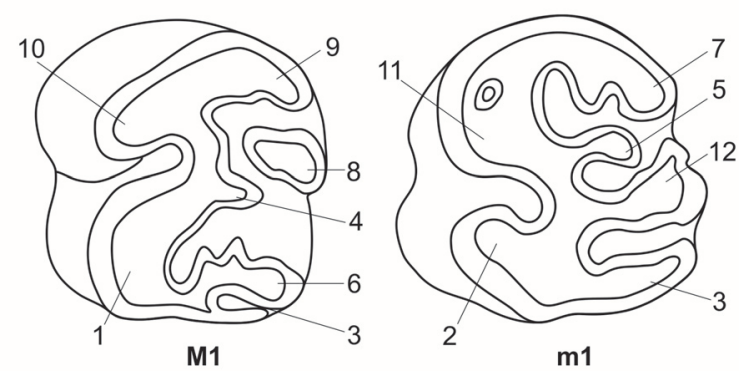

FIGURE 1. Dental terminology used in this paper (after Topachevsky, 1969; Sarica and Şen, 2003): 1, hypocone; 2, hypoconid; 3, posterior collar; 4, mesocone; 5, mesoconid; 6, metacone; 7, metaconid; 8, paracone; $\mathbf{9}$, anterior collar; 10 , protocone; 11 , protoconid; 12 , entoconid.

On the paracone near the OES, the IPM is almost completely lacking of prisms (Figure 2.2, 2.6). On the lingual side of the tooth, the PLEX is not pronounced. The lamellar type near the EDJ has a typical structure (Figure 2.3, 2.5). The boundary between the two main enamel types is clearly visible even though the IPM structures bound together smoothly and gradually. The enamel of the metaflexus and mesoflexus consists of only the radial type with linear IPM structures and prisms, especially near the OES (Figure 2.1).

Similarly to M1, the enamel of M2 (Figure 3.16) consists of linearly arranged structures of the radial type constituting $60 \%$ of the total enamel thickness and rather interwoven structures of the lamellar layer, which is up to $40 \%$ of the thickness. Unlike the M1, the lamellar enamel is narrower than the radial one on the hypocone and also reappears on the metacone and paracone. In addition, the lamellar type has more primitive structure (i.e., the interlacement of poorly developed prisms is not clearly expressed; see von Koenigswald (1980) for details) compared to that of M1 (Figure 3.1, 3.4). The radial enamel adjacent to the OES is always accompanied by a weak PLEX, which disappears at the narrowing of the lamellar type (Figure 3.4). The boundary between the radial and lamellar layers is clearly visible though not sharp (Figure 3.3). The radial enamel is the only type on the hypocone and paraflexus. The prisms are vertically oriented. The same structure is also observed on metaflexies.

The $\mathrm{m} 1$ enamel consists of two types (radial and lamellar) and remains along the entire perimeter of the tooth (Figure 4.1-4). The radial enamel possesses an IPM of the linear structure with delicately packed prisms. The lamellar type is about 

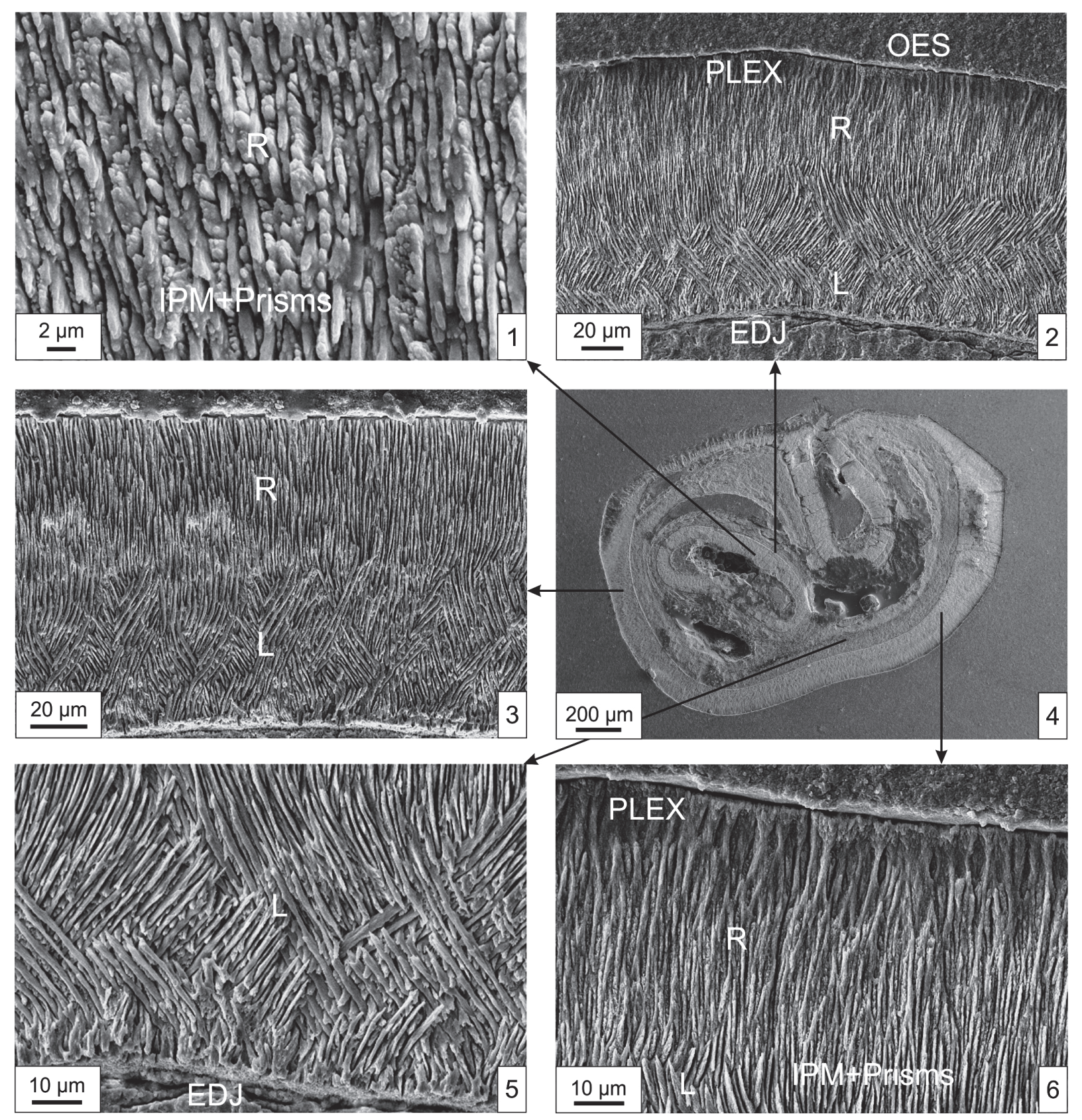

FIGURE 2. Ultrastructure of the right M1 enamel of †Anomalomys gaillardi from the late Miocene (MN 9) of Grytsiv, Ukraine (NMNHU-P 22/2417).

$40 \%$ of the total enamel thickness. It has nondecussated structure in places of its tapering on the hypoconid and protoconid (Figure 4.3). The radial enamel forms a poorly structured PLEX type (except for the hypoconid). The lamellar enamel is absent on flexids and fossettids. The structure of radial enamel is generally similar to that on other teeth except the somewhat chaotic arrangement of rough prisms towards the OES.
A special feature of the $\mathrm{m} 2$ (Figure $5.1-4$ ) is a poorly developed and primitive lamellar enamel located only on the meta-, meso-, and entoconids. It occupies $20 \%$ of the total enamel thickness, and the IPM structures are slightly interwoven and filled up with prisms (Figure 5.1). In the areas where the lamellar enamel is present, a weak PLEX appears at the OES (Figure 5.4). 

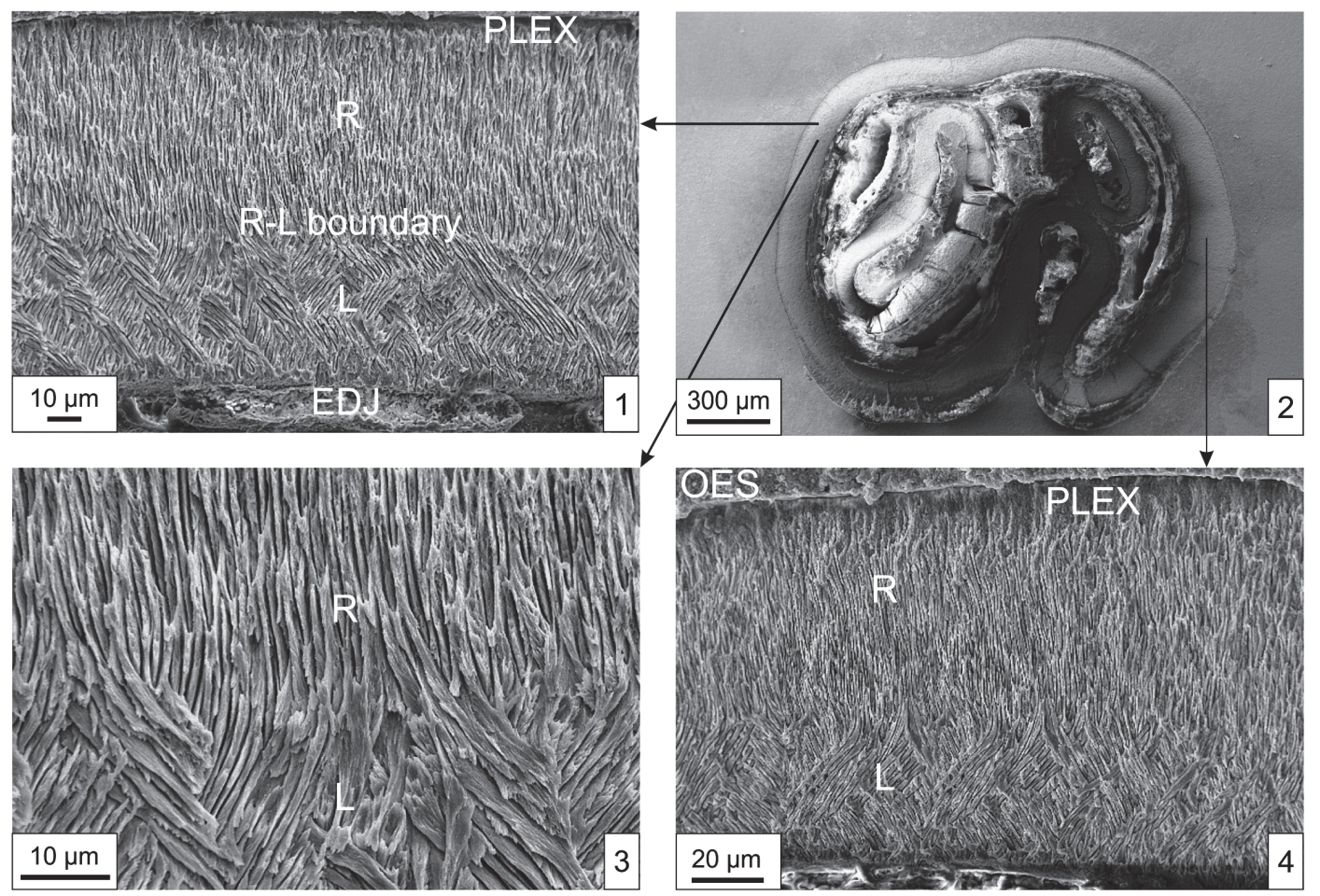

FIGURE 3. Ultrastructure of the left M2 enamel of †Anomalomys gaillardi from the late Miocene (MN 9) of Grytsiv, Ukraine (NMNHU-P 22/2548).
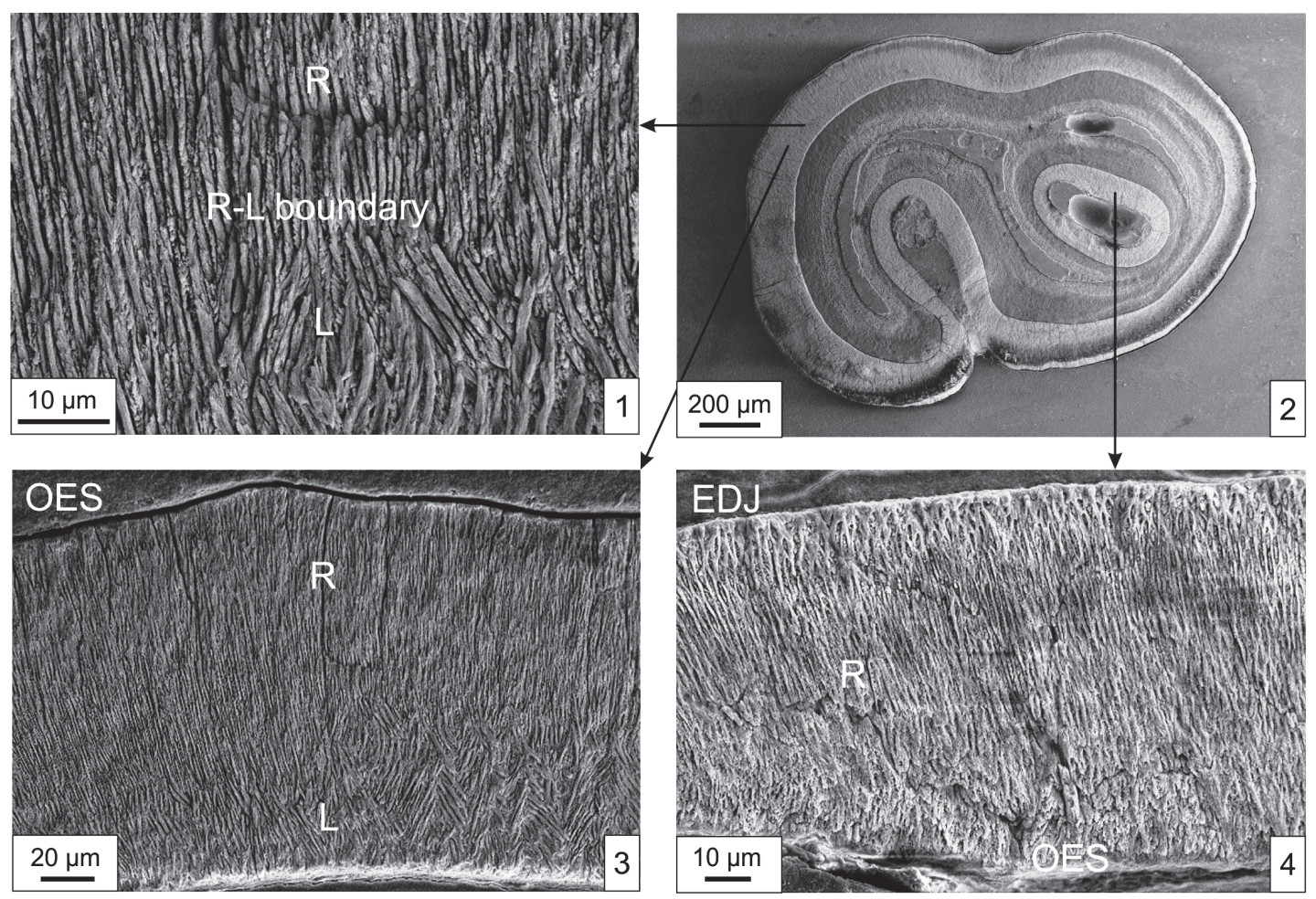

FIGURE 4. Ultrastructure of the left $\mathrm{m} 1$ enamel of †Anomalomys gaillardi from the late Miocene (MN 9) of Grytsiv, Ukraine (NMNHU-P 22/2261). 


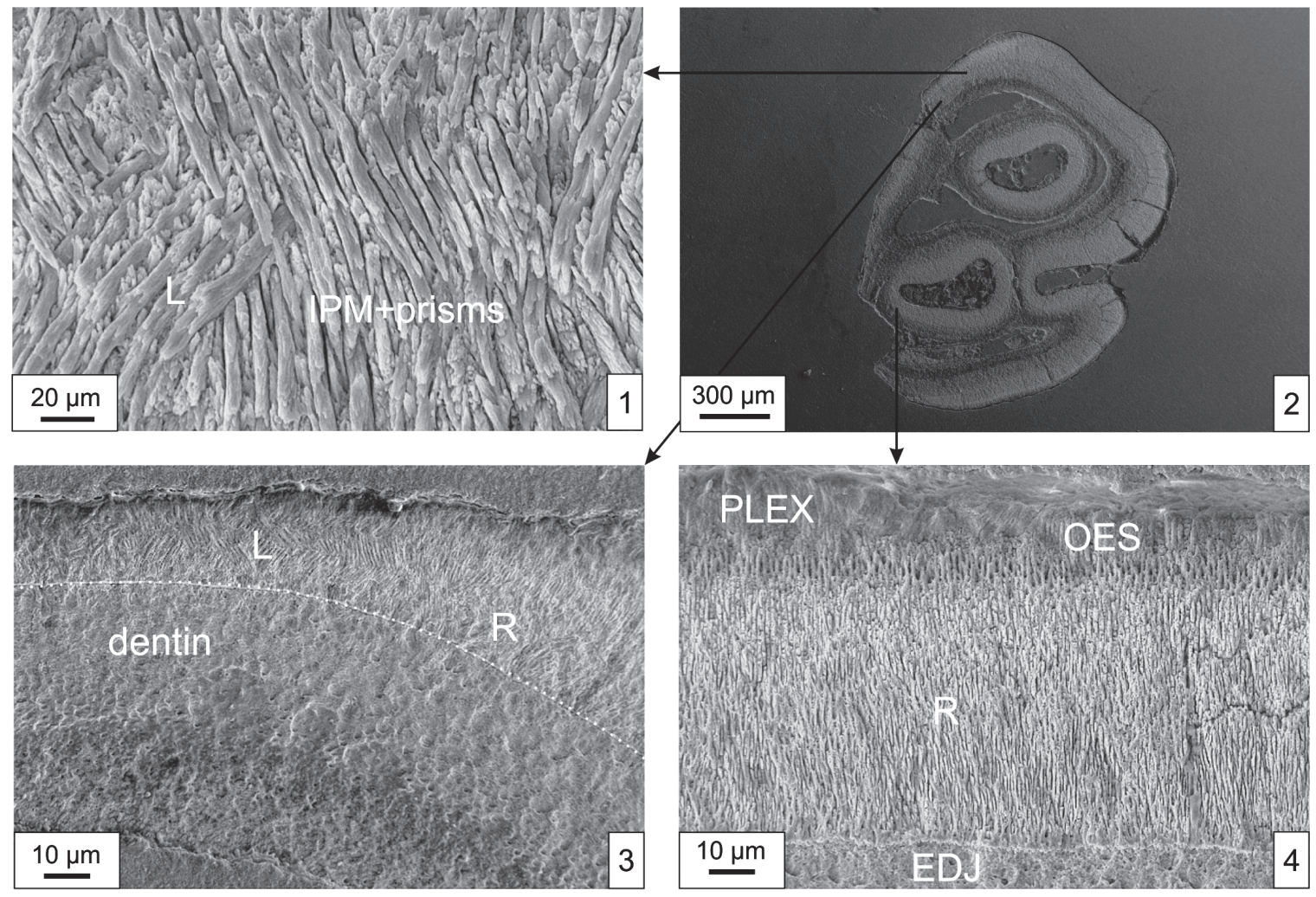

FIGURE 5. Ultrastructure of the left $\mathrm{m} 2$ enamel of †Anomalomys gaillardi from the late Miocene (MN 9) of Grytsiv, Ukraine (NMNHU-P 22/2326).

The enamel of $\mathrm{m} 3$ (Figure 6.1-6) on the protoconid and metaconid is two-layered with the lamellar type of a primitive structure and poorly developed PLEX (up to $20 \%$ of the total enamel thickness; Figure 6.1, 6.3). Crystallites of the IPM anastomose between prisms and become obvious where prisms are sectioned obliquely (Figure 6.5). In places where the lamellar enamel is present, a weak PLEX is also usually developed. On the fossettids, only radial enamel is present with rough IPM structure and single prisms (Figure 6.2). The enamel structure on the hypoconid is of particular interest. The radial enamel is almost completely lacking of IPM and consists of prisms inclined to the OES. Near this boundary, lenticular structures of different sizes and arranged in parallel are observed (Figure 6.6). According to von Koenigswald (pers. comm., 2014), they might represent dry cracks of the enamel.

Remarks. The enamel structure of all examined molars in †Anomalomys gaillardi is generally the same having two clearly defined types - a welldeveloped radial and a less developed lamellar. The latter is mostly represented along the perimeter of the upper molars. Typically, this enamel type is absent on the protoconids and hypoconids of the lower molars or it is presented here by a primitive variation. The PLEX can be present together with the lamellar enamel type along the tooth perimeter. In addition, the radial enamel near the EDJ often forms a reticularly arranged IPM, which sometimes lacks of prisms. The enamel of the flexus shows the radial enamel type only. A specificity of the cracks and the arrangement of prisms revealed on the $\mathrm{m} 3$ hypoconid require additional explanation. Such a complex structure of the enamel of molars in †Anomalomys compared to Spalacidae probably reflects their grass feeding in Miocene steppe landscapes (Kowalski, 1994; Topachevsky et al., 1996).

Family SPALACIDAE Gray, 1821

Genus †PLIOSPALAX Kormos, 1932

†Pliospalax macoveii (Simionescu, 1930)

Figure 7

Material. Two M3, Krasnopol (early Pliocene, MN 14), southern Ukraine.

Description. Only the radial enamel is visible along the perimeter of M3 (Figure 7.1-6) formed of very thin IPM, which is arranged strictly parallel or forms a reticulate structure (Figure 7.1-3). Near the EDJ, decussation of the matrix is clearly visible and better pronounced (Figure 7.2). Cells of the matrix 

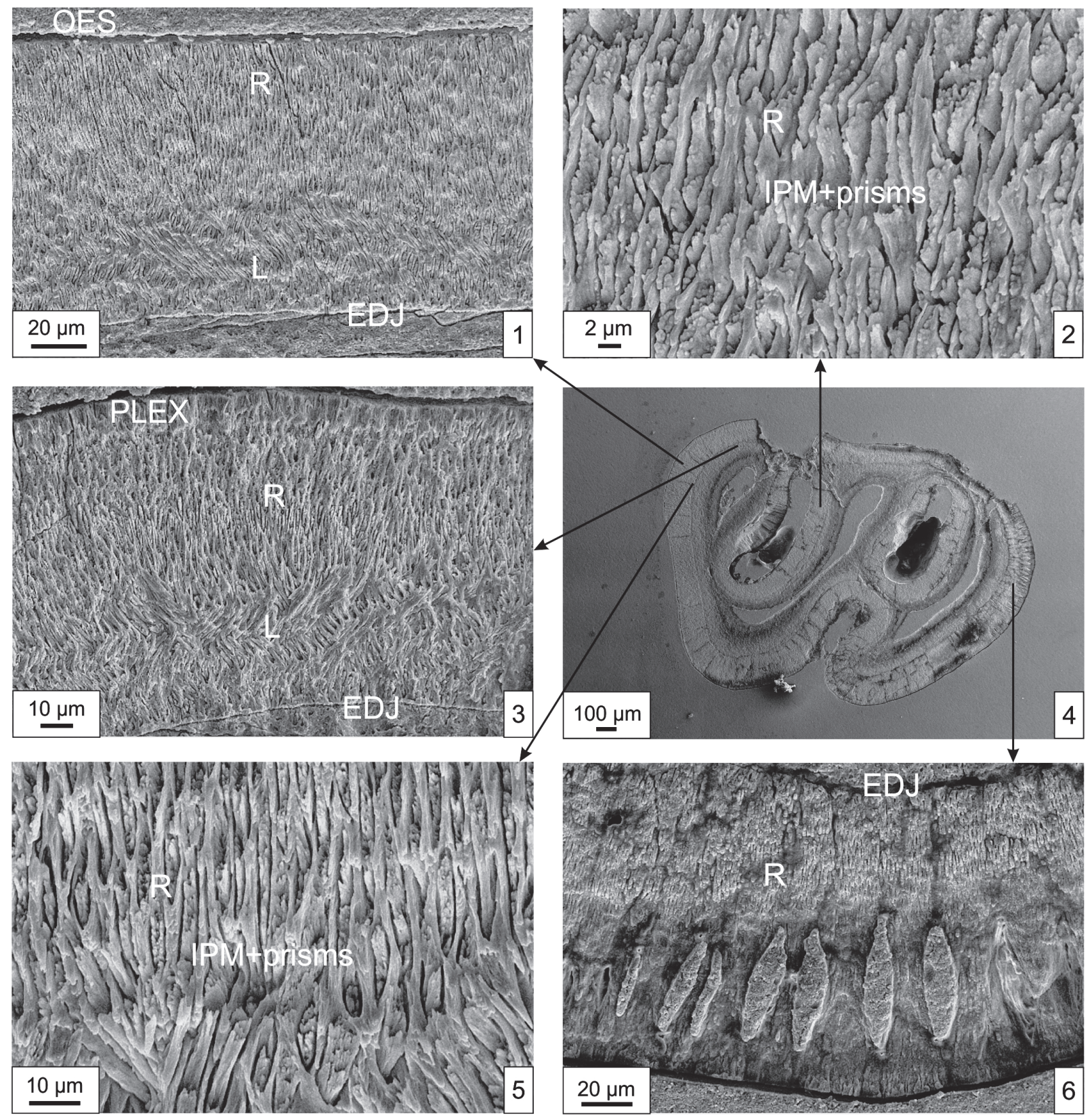

FIGURE 6. Ultrastructure of the right $\mathrm{m} 3$ enamel of $†$ Anomalomys gaillardi from the late Miocene (MN 9) of Grytsiv, Ukraine (NMNHU-P 22/2392).

are of lenticular shape, filled with distinct and very small prisms (Figure 7.5). The same structure of the radial enamel is characteristic for the flexies. Prisms are very small and stacked randomly in the matrix. Closer to the OES, the IPM forms the PLEX (Figure 7.3, 7.6). The lamellar enamel in Pliospalax has not been identified.

†Pliospalax odessanus (Topachevsky, 1969) Figure 8
Material. Two M3, Odesa Catacombs (middle Pliocene, MN 15), southern Ukraine.

Description. The enamel on the M3 (Figure 8.1-6) is represented by two types. The radial one occupies $70-80 \%$ of the total enamel thickness, while the rest is the PLEX. The IPM is represented by thin parallel elements and contains small single prisms inclined to the EDJ (especially in the middle part; Figure 8.3). At the EDJ, a reticulate IPM structure is visible, with its long cells filled with prisms 


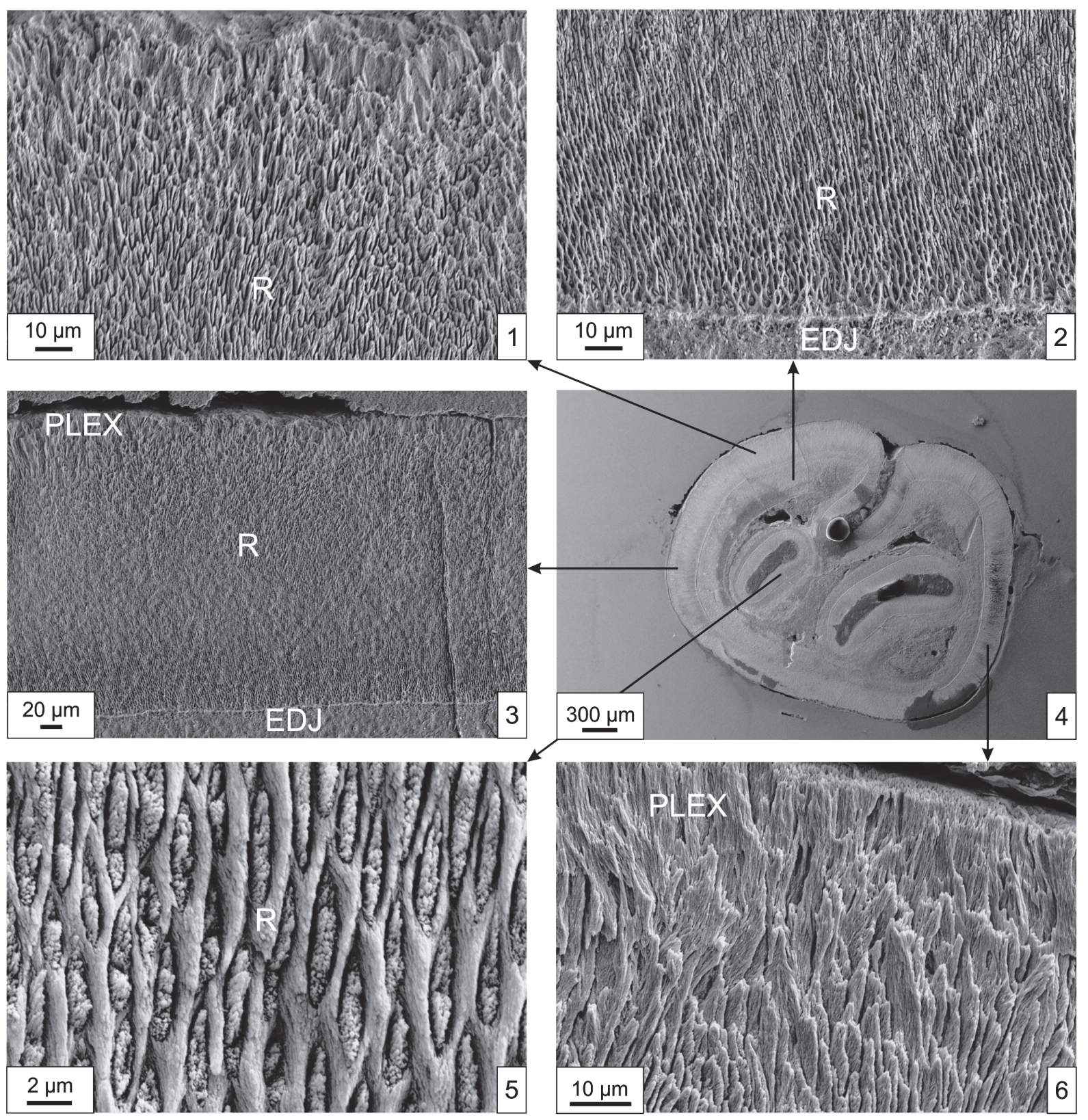

FIGURE 7. Ultrastructure of the right M3 enamel of †Pliospalax macoveii from the early Pliocene (MN 14) of Krasnopol, Ukraine (NMNHU-P 37/325).

inclined to the EDJ. At the OES, there is a quite well-defined and relatively thick PLEX enamel (Figure 8.5-6). The enamel on the fossettes and flexies is of the radial type. The IPM elements are well developed and arranged in parallel or decussating. The gaps between IPM are filled with small prisms (Figure 8.1, 8.3). There are no modifications of the radial layer at the OES or EDJ.

\section{Genus SPALAX Güldenstaedt, 1770 †Spalax minor Topachevsky, 1959 \\ Figure 9}

Material. Two M2, Tarkhankut (late Pleistocene, MQR 8), Crimea, southern Ukraine.

Description. The enamel along the $\mathrm{m} 2$ (Figure 9.1-4) is formed by the radial type ( $90 \%$ of its total thickness) and the primitive PLEX, especially at the OES. IPM cells are not always completely filled with prisms (Figure 9.1-2, 9.4). The radial enamel 

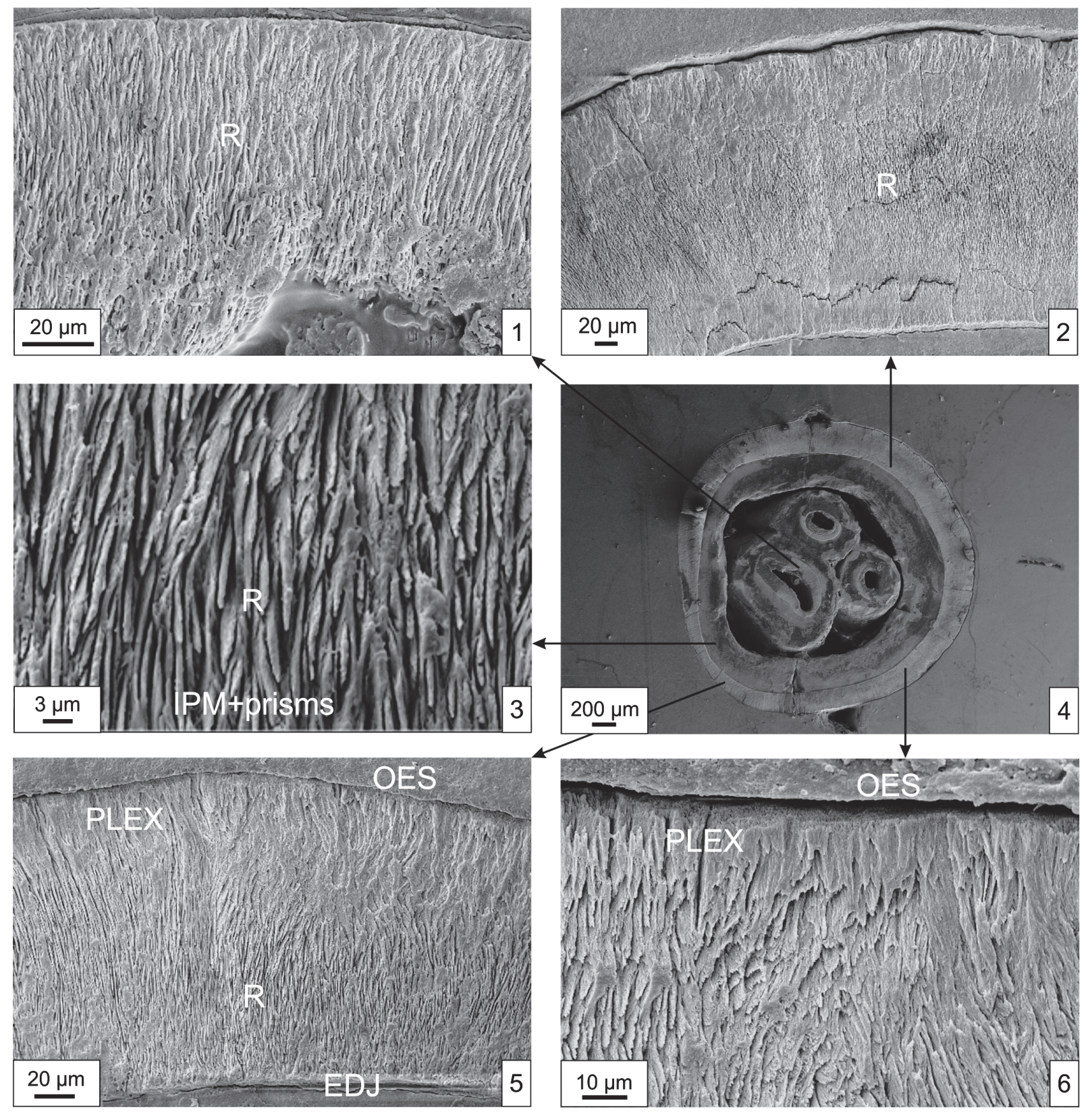

FIGURE 8. Ultrastructure of the right M3 enamel of †Pliospalax odessanus from the middle Pliocene (MN 15) of Odesa Catacombs, Ukraine (NMNHU-P O/1328).

is composed of very small IPM elements arranged linearly and parallel (Figure 9.2). These structures resemble a very small reticulum, especially near the EDJ. The IPM cells are elongated and lenticular, small-sized, and filled with small individual prisms inclined to the OES (Figure 9.1, 9.4). Flexies and fossettes have a very similar enamel structure composed of the radial enamel type with densely packed prisms and IPM. The weakly developed PLEX is visible near the OES.

Remarks. The enamel structure in †Spalax minor is generally similar to that in Pliospalax macoveii from Krasnopol. However, there are differences in the enamel structure in the spalacid species from Odesa Catacombs where a PLEX-HSB is composed of coarse elements. 

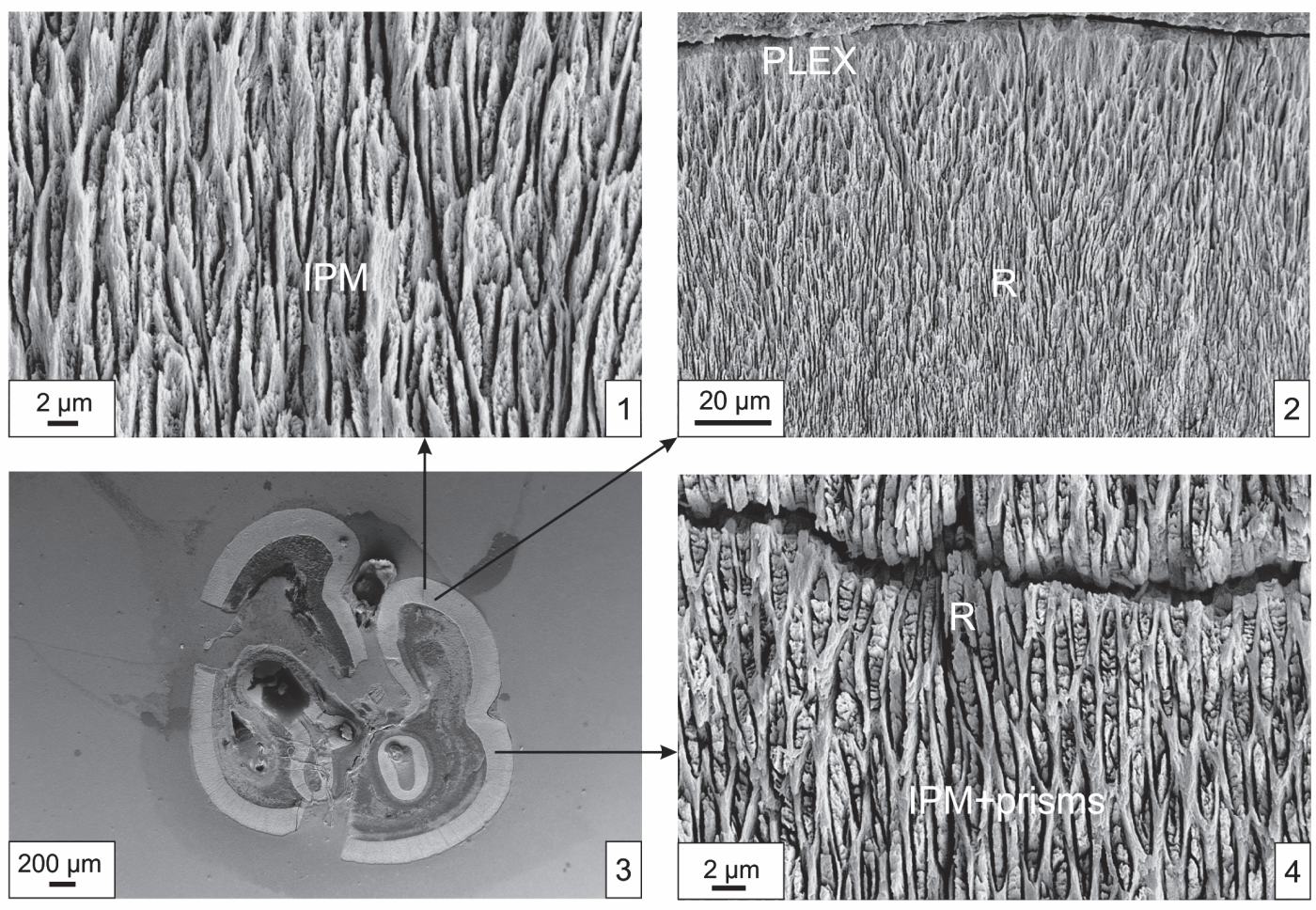

FIGURE 9. Ultrastructure of the right M2 enamel of †Spalax minor from the late Pleistocene (MQR 8) of Tarkhankut, Crimea, Ukraine (NMNHU-P 50/1302).

\section{Spalax microphthalmus Güldenstaedt, 1770}

Figure 10

Material. Two M3, Recent, southern Ukraine.

Description. The M3 (Figure 10.1-6), with two fossettes and a hypoflexus, belongs to an adult individual. The entire enamel along the tooth perimeter consists of the radial type. In some places, a slightly reticulate IPM structure is visible (Figure $10.1,10.5)$. The enamel is more primitive than in Spalax leucodon (see below). At the OES, the IMP forms a non-structured thin PLEX (Figure 10.6). The enamel on the flexies also consists only of the radial type but of a somewhat different arrangement of the IPM and prisms. From both sides of the flexus, the matrix has a mostly reticulate structure with prisms. At the same time, prisms are absent as well on the most folded areas of the tooth surface (Figure 10.1-2). Along the entire perimeter near the EDJ, a very thin PLEX is clearly visible. The enamel on the same flexus can be composed of reticulate and linear IPM structures filled with prisms. A thin PLEX enamel is visible closer to the OES (Figure 10.4).

Spalax leucodon (Nordmann, 1840) Figure 11

Material. Two M3, Recent, southern Ukraine.
Description. The studied M3 (Figure 11.1-6) belongs to an adult individual; the tooth is worn, retaining fossettes but hypostria is already lacking. The enamel along the tooth perimeter consists almost entirely of radial enamel only, which is significantly differentiated in width. The enamel is represented by four distinct structural modifications. First, the radial enamel, which is located near the EDJ, occupies about $30-35 \%$ of the total width. The IPM is relatively rough having a clear reticulate structure; its cells are filled with relatively fine individual prisms, while the prisms are absent closer to the EDJ (Figure 11.2, 11.5). Modification of the middle layer of the radial enamel is characterized by thin and fine IPM structures, which are arranged linearly, tightly packed together, and the gaps between them are filled with prisms (Figure 11.2). This is the most densely stacked variation of the radial enamel; it takes about $40 \%$ of the total enamel width. The boundary between the reticulate and linear enamels is not so sharp, but quite clearly visible. Closer to the OES, the linear structure of the IPM is relatively quickly replaced by non-structural and looking as obliquely cutting IPM elements with no prisms (Figure 11.1-2). It occupies no more than $10 \%$ of the total enamel thickness. The PLEX is visible near the OES (Figure 


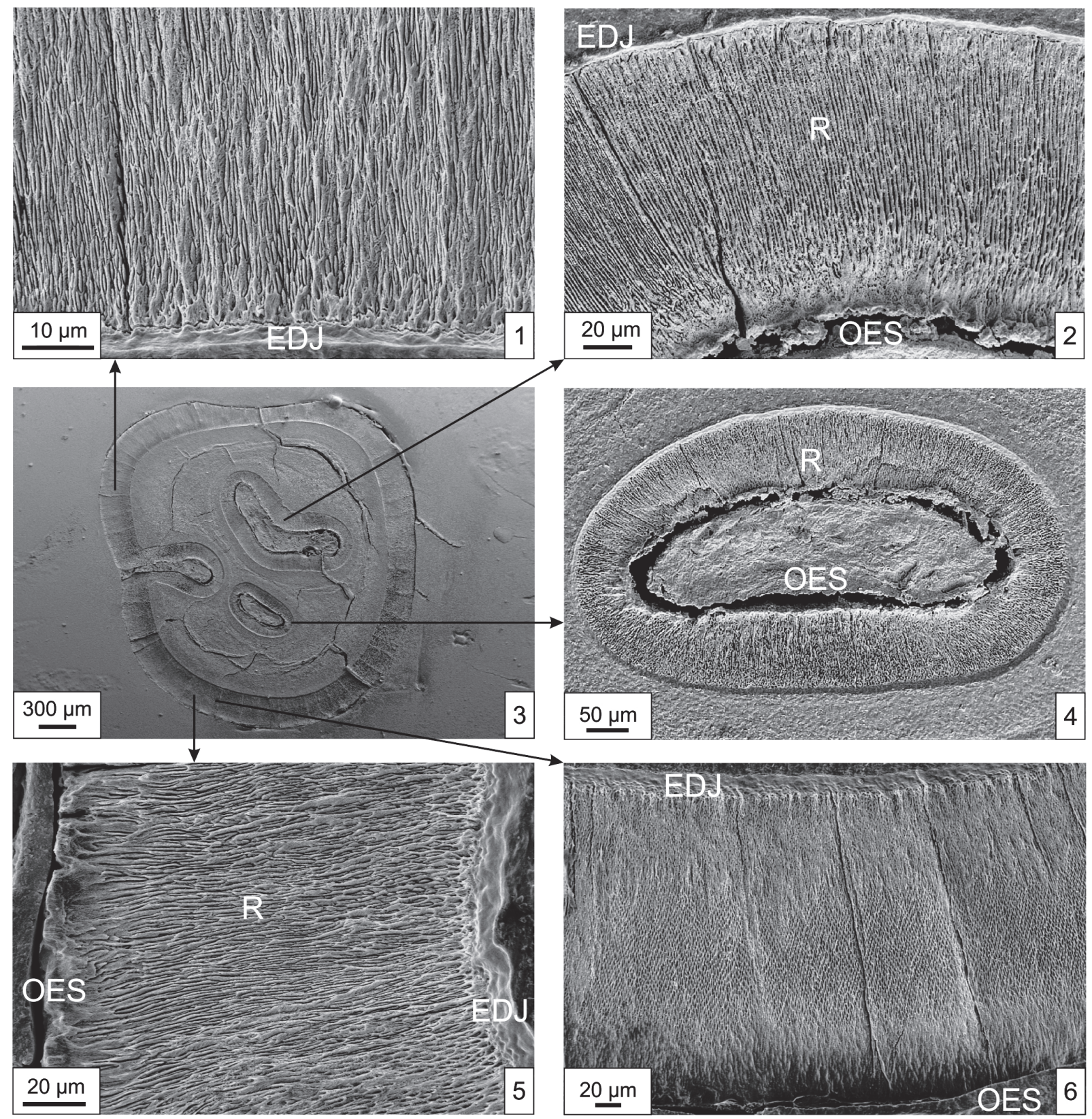

FIGURE 10. Ultrastructure of the right M3 enamel of recent Spalax microphthalmus from Ukraine (NMNHU-P 4839).

11.2). The radial enamel is retained with amorphous IPM structures and a small number of prisms in some parts of the tooth perimeter.

The enamel on fossettes also consists only of the radial type. The IPM (Figure 11.1, 11.3) has a rough or fine linear structure (Figure 11.1) composed by small prisms. At the EDJ, the IPM forms a thin (up to $5 \%$ of the enamel width) layer with reticulate structure and a small number of prisms
(Figure 11.3, 11.6). Near the OES, a weak PLEX (up to $10 \%$ ) is observed.

Remarks. Both recent species (Spalax microphthalmus and $S$. leucodon) are characterised by the presence of more primitive enamel especially on flexies and fossettes, where the enamel is highly differentiated. The tooth enamel in Spalax microphthalmus is assumed more primitive regarding its structure and variations of the radial type compared to that in Spalax leucodon. 


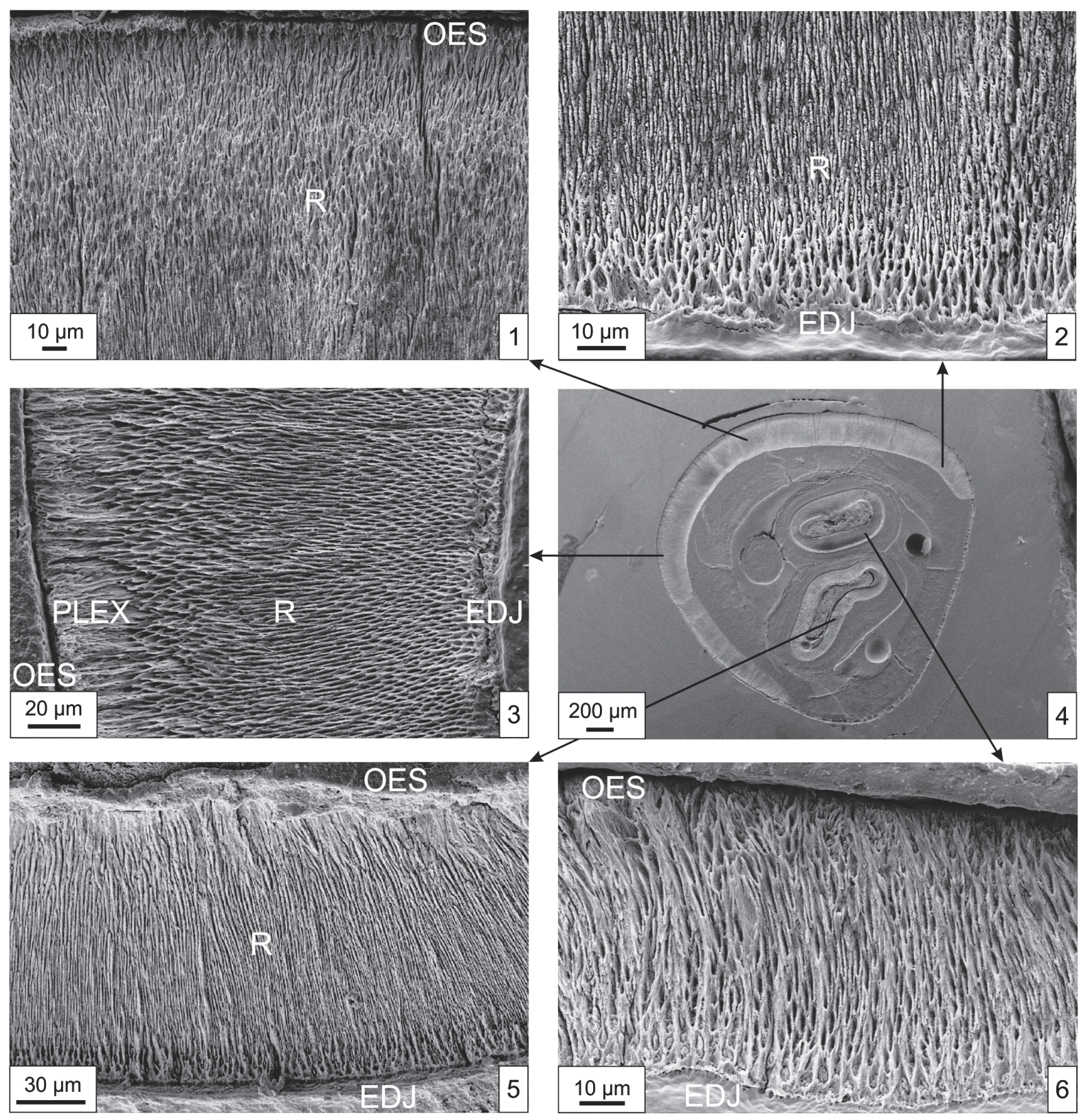

FIGURE 11. Ultrastructure of the right M3 enamel of recent Spalax leucodon from Ukraine (NMNHU-P 2238/6).

\section{DISCUSSION}

Analysis shows that the ultrastructure of tooth enamel in †Anomalomys gaillardi from the late Miocene of Ukraine clearly differs from that in representatives of the family Spalacidae of Pliocene and Pleistocene age. It is two-layered (lamellar and radial enamel types) in †Anomalomys but usually consists of the radial enamel only in Spalacidae. The formation of the primitive PLEX is associated with the lamellar type. The enamel of the flexus and fossettes in all compared forms consists only of the radial type with different arrangement of prisms and IPM.

In terms of the enamel structure, †Spalax minor is rather close to †Pliospalax macoveii both having the radial layer with a fine-prismatic structure along the tooth perimeter on the flexies and fossettes. These two species also have poorly developed and relatively primitive PLEX enamel. Based on these data, we assume that these spe- 
cies are closely related. Such opinion is in agreement with the results of the analysis of dental features provided by Şen and Sarica (2011): †Pliospalax and Spalax are grouped into the same clade because of the absence of synapomorphy to distinguish the species referred to these genera. At the same time, the morphology of the enamel in †Pliospalax odessanus from the Odesa Catacombs significantly differs from that in all other studied taxa. This is indicated by a strictly linear arrangement of prisms and IPM.

As for recent Spalax leucodon and Spalax microphthalmus, the first species is characterized by having a more progressive enamel type. As compared to the studied extinct (late Miocene and Pliocene) spalacids, the enamel of both recent species is more primitive. †Anomalomys from the late Miocene is the most divergent form having regularly arranged and complex lamellar enamel. Compared to †Anomalomys, Pliocene spalacids have more primitive enamel, although it is more advanced than in recent species of Spalax (Rekovets and Maul, 2016).
The enamel structure molars in †Anomalomys gaillardi is more complex than that in succeeding Spalacidae. This may additionally support the view (Fejfar, 1972; Klein Hofmejer and de Bruijn, 1985; de Bruijn and Saraç, 1991; Bendukidze et al., 2009; de Bruijn et al., 2015) that anomalomyids and spalacids are distantly related and they evolved independently. We share the opinion of Şen and Sarica (2011) that similar morphological features shared by representatives of the families †Anomalomyidae and Spalacidae reflect their fossorial adaptations (Topachevsky, 1969; Bolliger, 1999), and therefore most likely indicate an evolutionary convergence.

\section{ACKNOWLEDGEMENTS}

We express our sincere thanks to four anonymous reviews for their multiple corrections, useful comments, and advice. We are very thankful to Z. Barkaszi for proofreading the text. We further thank the handling editor M. Hyžný and the whole editorial crew of Palaeontologia Electronica for the positive evaluation of our manuscript.

\section{REFERENCES}

Bendukidze, O.G., de Bruijn, H., and van den Hoek Ostende, L. 2009. A revision of Late Oligocene associations of small mammals from the Aral Formation (Kazakhstan) in the National Museum of Georgia, Tbilisi. Palaeodiversity, 2:343-377.

Bolliger, T. 1999. Family Anomalomyidae, 389-394 in Rössner, G.E. and Heissig, K. (eds.), The Miocene Land Mammals of Europe. Verlag Dr. Friederich Pfeil, München.

de Bruijn, H. 1984. Remains of the mole-rat Microspalax odessanus Topachevski, from Karabumn (Greece, Macedonia) and the family Spalacidae. Proceedings Koninklijke Nederlandse Akademie van Wetenschappen B, 87:417-425.

de Bruijn, H., Bosma, A.A., and Wessels, W. 2015. Are the Rhizomyinae and the Spalacinae closely related? Contradistinctive conclusions between genetics and palaeontology. Palaebiodiversity and Palaeoenvironments, 95:257-269. https://doi.org/10.1007/s12549-0150195-y

de Bruijn, H. and Saraç, G. 1991. Early Miocene faunas from the eastern Mediterranean area. Part 1. The genus Eumyarion. Proceedings Koninklijke Nederlandse Akademie van Wetenschappen $B, 94: 1-36$.

Fejfar, O. 1972. Ein neuer Vertreter der Gattung Anomalomys Gaillard, 1900 (Rodentia, Mammalia) aus dem europäischen Miozän (Karpat). Neues Jahrbuch für Paläontologie, Abhandlungen, 141:168-193.

Flynn, L.J., Nevo, E., and Heth, G. 1987. Incisor enamel microstructure in blind mole rats: adaptive and phylogenetic significance. Journal of Mammalogy, 68:500-507. https://doi.org/ 10.2307/1381586

Gaillard, C. 1900. Sur un nouveau rongeur miocène. Comptes rendus de l'Académie des sciences Paris, 130:191-192.

Gray, J.E. 1821. On the natural arrangement of vertebrose animals. London Medical Repository, 15:296-310.

Güldenstaedt, A.I. 1770. Peregusna nova mustelae species. Novi Commentari Academiae Scientiarum Imperialis Petropolitanae, 14:441-455.

Hugueney, M. and Mein, P. 1993. A Comment on the Earliest Spalacinae (Rodentia, Muroidea). Journal of Mammalian Evolution, 1:215-223. https://doi.org/10.1007/BF01024708 
Kalthoff, D.C. 2000. Die Schmelzmikrostruktur in den Incisiven der hamsterartigen Nagetiere und anderer Myomorpha (Rodentia, Mammalia). Palaeontographica Abteilung A, 259:1-193.

Klein Hofmeijer, G. and de Bruijn, H. 1985. The mammals from the lower Miocene of Aliveri (island of Evia, Greece). Part 4: The Spalacidae and Anomalomyidae. Proceedings Koninklijke Nederlandse Akademie van Wetenschappen B, 88:185-198.

Kormos, T. 1932. Neue pliozane Nagetiere aus der Moldau. Paläontologische Zeitschrift, 14:193200.

Kowalski, K. 1994. Evolution of Anomalomys Gaillard, 1900 (Rodentia, Mammalia) in the Miocene of Poland. Acta Zoologica Cracoviensia, 37:163-176.

Loch, C., Kieser, J.A., and Fordyce, R.E. 2015. Enamel Ultrastructure in Fossil Cetaceans (Cetacea: Archaeoceti and Odontoceti). PLoS ONE, 10:e0116557. https://doi.org/10.1371/ journal.pone.0116557

Martin, T. 1993. Early rodent incisor enamel evolution: phylogenetic implications. Journal of Mammalian Evolution, 1:227-254. https://doi.org/10.1007/BF01041665

Martin, T. 1997. Incisor enamel microstructure and systematics in rodents, 163-175. In von Koenigswald, W. and Sander, P. (eds.), Tooth Enamel Microstructure. Balkema, Rotterdam.

Martin, T. 2004. Evolution of incisor enamel microstructure in Lagomorpha. Journal of Vertebrate Paleontology, 24:411-426. https://doi.org/10.1671/2513

Méhely, L. 1809. Species generis Spalax. Die arten der blindmäuse in systematischer und phylogenetische Beziehung. Mathematische und naturwissenschaftliche Berichte aus Ungarn, 28:1-390.

Mein, P. 1999. European Miocene mammal biochronology, 73-90. In Rössner, G.E. and Heissig, K. (eds.), The Miocene Land Mammals of Europe. Verlag, Dr. Friedrich Pfeil, München.

Mein, P. and Freudenthal, M. 1971. Une nouvelle classification des Cricetidae (Mammalia, Rodentia) du Tertiair de l'Europe. Scripta Geologica, 2:1-37.

Nesin, V.A. and Nadachowski, A. 2001. Late Miocene and Pliocene small mammal faunas (Insectivora, Lagomorpha, Rodentia) of Southeastern Europe. Acta Zoologica Cracoviensia, 44:107-135.

Nordmann, A. 1840. Observations sur la Faune Pontique. Mammalia. Voyage dans la Russie méridionale et la Crimee, 3:1-65. E. Bourdin et Cet., Paris.

Rabiniak, E., Rekovets, L.I., and Nowakowski, D. 2017. Dental enamel ultrastructure in Ochotona and Prolagus (Mammalia: Lagomorpha: Ochotonidae) from three late Miocene localities in Ukraine. Palaeontologia Electronica, 20.3.46A:1-12. https://doi.org/10.26879/588 http://palaeo-electronica.org/content/2017/1998-enamel-ochotona-and-prolagus

Rekovets, L.I. and Kovalchuk, O.M. 2017. Phenomenon in the Evolution of Voles (Mammalia, Rodentia, Arvicolidae). Vestnik Zoologii, 51:99-110. https://doi.org/10.1515/vzoo-2017-0015

Rekovets, L.I. and Maul, L. 2016. New evidence for the evolutionary history of spalacine and anomalomyine rodents, 268-269, In Arkadiev, V.V., Bogdanova, T.N., Bugrova, E.M., Vuks, V.Ya., Yevdokimova, I.O., Ivanov, A.O., Kossovaya, O.L., Kotlyar, G.V., Nikolaeva, I.A., Oshurkova, M.V., Raievskaya, E.G., Sapelko, T.V., Suyarkova, A.A., Tesakov, A.S., Titov, V.V. and Tolmacheva, T.Yu. (eds.), 100th anniversary of the Paleontological Society of Russia. Problems and prospects of paleontological research. Materials of the LXII session of the Paleontological Society at the Russian Academy of Sciences (April 4-8, 2016, St. Petersburg). VSEGEI, Saint-Petersburg.

Rekovets, L. and Nowakowski, D. 2013. Zahlschmelz-Ultrastructuren an Backenzahen verschierdener Vertreter der Familie Castoridae (Rodentia, Mammalia) aus der Ukraine. Säugetierkundliche Informationen, 2013:159-163.

Rekovets, L.I., Nowakowski, D., and Dema, L.P. 2015. The molar enamel ultrastructure of the Miocene-Pliocene Spalacidae and Anomalomyidae (Rodentia, Mammalia) of Ukraine, 96-97. In Bucur, I.I., Lazăr, I., and Săsăran, E. (eds.), Tenth Romanian Symposium on Paleontology (October 16-17, 2015), Cluj-Napoca, Romania.

Sarica, N. and Şen, S. 2003. Spalacidae (Rodentia), 141-162. In Fortelius, M., Kappelman, J., Şen, S., and Bernor, R.L. (eds.), Geology and Paleontology of the Miocene Sinap Formation, Turkey. Columbia University Press, New York.

Schaub, S. 1925. Die Hamsterartigen Nagetiere des Tertiars. Abhandlungen der Schweizerischen Paläontologischen Gesellschaft, 45:66-68.

Şen, S. and Sarica, N. 2011. Middle-Late Miocene Spalacidae (Mammalia From Western Anatolia, and the Phylogeny of the Family. Yerbilimleri - Bulletin of the Earth Sciences, 32:21-50. 
Simionescu, I. 1930. Vertebratele Pliocene de la Maluşteni (Covurlui). Publications du Fondation Vasile Adamachi, Akademia Romana, 9:83-151.

Stefen, C. 1999. Enamel microstructure of recent and fossil Canidae (Carnivora: Mammalia). Journal of Vertebrate Paleontology, 19:576-587. https://doi.org/10.1080/ 02724634.1999 .10011166

Topachevsky, V.O. 1959. A new species of mole rat from the Upper Pliocene deposits of the south of USSR. Dopovidi Natsionalnoi Akademii Nauk Ukrainy, 11:1262-1266. (In Ukrainian)

Topachevsky, V.A. 1969. Slepyshovye (Spalacidae). Nauka, Leningrad (Fauna of the USSR, Mammals, 3; vol. 3).

Topachevsky, V.A., Nesin, V.A., and Topachevsky, I.V. 1997. An Essay of the Small Mammal Fauna History (Insectivora, Lagomorpha, Rodentia) in Ukraine during Middle SarmatAktshagyl Period. Vestnik Zoologii, 31:3-14. (In Russian)

Topachevsky, V.A, Nesin, V.A., and Topachevsky, I.V. 1998. Biozonal microtheriological scheme (stratigraphic distribution of small mammals - Insectivora, Lagomorpha, Rodentia) of Neogene of the northern part of Eastern Paratethys. Vestnik Zoologii, 32:76-87. (In Russian)

Topachevsky, V.A., Nesin, V.A., Topachevsky, I.V., and Semenov, Y.A. 1996. The oldest middle Sarmatian locality of small mammal fauna (Insectivora, Lagomorpha, Rodentia) in Eastern Europe. Dopovidi Natsionalnoi Akademii Nauk Ukrainy, 2:107-110. (In Russian)

Viret, J. and Schaub, S. 1946. Le genre Anomalomys, rongeur néogène et sa repartition stratigraphique. Eclogae Geologicae Helvetiae, 39:342-352.

von Koenigswald, W. 1997a. The variability of the enamel at the dentition level, 93-201. In von Koenigswald, W. and Sander, P.M. (eds.), Tooth Enamel Microstructure. Balkema, Rotterdam.

von Koenigswald, W. 1997b. Evolutionary trends in the differentiation of mammalian enamel ultrastructure, 203-235. In von Koenigswald, W. and Sander, P.M. (eds.), Tooth Enamel Microstructure. Balkema, Rotterdam.

von Koenigswald, W. 1980. Schmelzstruktur und Morphologie in den Molaren der Arvicolidae (Rodentia). Abhandlungen der Senckenbergischen Naturforschenden Gesellschaft, 539:1129.

von Koenigswald, W. 2004. The three basic types of schmelzmuster in rodent molars and their occurrence in the various rodent clades. Palaeontographica, 270:95-132.

von Koenigswald, W. and Martin, L.D. 1984. Revision of the fossil and recent Lemminae (Rodentia, Mammalia), 122-137. In Mengel, R.M. (ed.), Papers In Vertebrate Paleontology Honoring R.W. Wilson. Carnegie Museum of Natural History Special Publication, 9.

von Koenigswald, W. and Mörs, T. 2001. The enamel microstructure of Anchitheriomys (Rodentia, Mammalia) in comparison with that of other beavers and of porcupines. Paläontologische Zeitschrift, 74:601-612. https://doi.org/10.1007/BF02988167

von Koenigswald, W. and Pfretzschner, H.U. 1991. Biomechanics in the Enamel of Mammalian Teeth, 113-125. In Schmidt-Kittler, N. and Vogel, K. (eds.), Constructional Morphology and Evolution. Berlin, Heidelberg, Springer.

von Koenigswald, W. and Sander, P. 1997. Glossary of terms used for enamel microstructure, 267-280. In von Koenigswald, W. and Sander, P. (eds.), Tooth Enamel Microstructure. Balkema, Rotterdam.

von Koenigswald, W., Sander, P.M., Leite, M.B., Mörs, T., and Santel, W. 1994. Functional symmetries in the schmelzmuster and morphology of rootless rodent molars. Zoological Journal of the Linnean Society, 110:141-179. https://doi.org/10.1006/zjls.1994.1008

von Koenigswald, W. and Tesakov, A. 1997. The evolution of the schmelzmuster in Lagurini (Arvicolinae, Rodentia). Palaeontographica Abteilung A, 245:45-61.

Wilson, D.E. and Reeder, D.M. 2005. Mammal Species of the World. A Taxonomic and Geographic Reference. Johns Hopkins University Press, Baltimore. 